предложенному определению, является основой получения предпринимательской структурой максимального дохода и прибыли.

1. Йеннер, Т. Создание и реализация потенциала успеха как ключевая задача стратегического менеджмента / Томас Йеннер // Проблемы теории и практики управления. - 2019. - №2. - С. 83-88.

2. Салютина, Т.Ю. Методология формирования и реализации аппарата анализа и планирования рыночного потенциала организаций связи: автореф. дис. на соискание науч. степени доктора экон. наук; спец. 08.00.05. «Экономика и упр. нар. хоз-вом» / Т.Ю.Салютина. - Московский технический университет связи и информатики (ГОУ ВПО МТУСИ). - Москва, 2010. $-25 \mathrm{c}$.

3. Визинский, А.Р. Определение сущности и структуры рыночного потенциала предприятия в условиях конкуренции / А.Р. Визинский, П.В. Воробьев // Научный альманах. - 2016. - №1(15). C.63-66.

4. Ефремов, А.Б. Механизм обоснования весового влияния локальных потенциалов различного уровня при оценке интегрального рыночного потенциала строительного предприятия / А.Б. Ефремов, В.С. Титаренко // Строительство и техногенная безопасность. - 2016. - №2(54). - С.19-22.

5. Зурин, М.В. Сущность рыночного потенциала предприятия / М.В. Зурин // Вестник Российского экономического университета имени Г.В. Плеханова. - 2013. - №6(60). - С.84-89.

6. Банчева, А. Оценка рыночного потенциала организации / А. Банчева // Маркетинг, 2007. - №3(94). - C.90-103.

7. Мальченкова, О. Разработка методики оценки уровня рыночного потенциала предприятия как основного направления совершенствования конкурентоспособности компании на рынке / O. Мальченкова, В. Циндяйкин // Риск: ресурсы, информация, снабжение, конкуренция. - 2012. - №2. - C.16-19.

8. Некрасов, А.В. оценка рыночного потенциала регионального полиграфического предприятия / А.В. Некрасов // Известия высших учебных заведений. Проблемы полиграфического дела. - 2008. - №3. - C.135-243.

9. Попов, Е.В. Рыночный потенциал предприятия: монография / Е.В. Попов. - М.: Экономика, 2002. $536 \mathrm{c}$.

10. Снитко, Л.Т. Значимость рыночного потенциала в стратегическом управлении предприятием / Л.Т. Снитко, Ю.А. Чужикова // Вестник Белгородского университета кооперации, экономики и права. 2015. - №2. - C.52-58.

11. Макущенко, М.П. Теоретические аспекты рыночного потенциала региона / М.П. Макущенко // Основы экономики, управления и права. - 2013. - №5(11). - С.50-54.

12. Воронков, А.А. Методы оценки рыночного потенциала предприятия средствами маркетинговой информационно-аналитической системы: автореф. дис. на соискание науч. степени кандидата экон. наук: спец. 08.00.05.- экономика и упр. нар. хоз-вом / А.А. Воронков. - Санкт - Петербургский государственный финансово-экономический университет. - С-Петербург, 2004. - 12c.

13. Котлер, Ф. Маркетинг менеджмент / Ф. Котлер, К.Л. Келлер; 12-е изд. - СПб.: Питер, 2009. -816с.

\title{
Шишолик И.А. \\ Модернизация организационной структуры Федеральной налоговой службы Российской Федерации
}

Забайкальский государственный университет

(Россия, Чита)

doi: $10.18411 / s r-05-12-2021-23$

\section{Аннотация}

Статья посвящена актуальной проблеме модернизации организационной структуры Федеральной налоговой службы, которая позволяет отразить ее преимущества и эффективность. Особое внимание уделяется процессу цифровизации и взаимодействию граждан с налоговыми органами.

Ключевые слова: Федеральная налоговая служба, модернизация, организационная структура, преобразование, цифровизация. 


\section{Abstract}

The article is devoted to the actual problem of the modernization in the organizational structure of the Federal Tax Service It allows to reflect its advantages and effectiveness. The special attention is dedicated for the process of digitalization and for the communication between citizens and tax authorities.

Keywords: Federal Tax Service, modernization, organizational structure, transformation, digitalization.

Актуальность данной темы не вызывает сомнения, так как процесс модернизации на сегодняшний день затрагивает все больше и больше органов государственной власти прежде всего это связано с развитием информационных технологий в мировом масштабе. На сегодняшний день назрела необходимость в выборе курса направленного на непрерывное совершенствование организационной деятельности, для того чтобы обеспечивать стабильное развития всех сфер жизнедеятельности общества и государства.

При написании работы, основу методологической базы составил комплекс методов научного познания и метод мониторинга.

Согласно стратегической карте ФНС России на 2020-2024 годы, налоговая служба постепенно переходит, на двухуровневую систему управления и укрупнения территориальных органов ФНС России[1]. В связи с этим, по всей стране пройдут масштабные мероприятия по реорганизации Инспекций путем присоединения к Управлению федеральной налоговой службы (далее УФНС) и укрупнению малочисленных инспекций.

Это говорит о том, что большое количество инспекций будет закрыто, а им на смену придут электронные сервисы, которые к слову уже сегодня позволяют, не выходя из дома решить любой вопрос, касаемый взаимодействия с налоговыми органами, будь то регистрация в качестве «самозанятого» или дача объяснений в рамках налогового контроля.

Так по состоянию на 01.01.2020 г. без посещения инспекции в качестве плательщика налога на профессиональный доход в России зарегистрировалось 3911 млн. человек, для этого просто необходимо скачать мобильное приложение[2].

Так же в настоящее время создано приложение для проверки кассового чека. Посредствам данного приложения можно сообщить в инспекцию, что вам не выдали чек.

Обращение посредствам электронных каналов связи поступит на рассмотрение инспектору, который проведет проверку по данному факту.

В будущем данный сервис будет работать без участия человека.

Однако в настоящее время, часть населения страны не имеет устойчивой сотовой связи.

Более чем в 25 тысяч населенных пунктов, услуги связи остаются недоступными, другая часть населения, например люди пенсионного возраста по состоянию на 1 января 2021 года их численность составляет 45637 тысяч человек доля, из которых не могут использовать современные информационные ресурсы[3].

Тем не менее, процесс преобразования запущен, об этом нам свидетельствует Постановление Правительства от 16.11.2020 №1830 «Об оптимизации структуры и численности федеральных государственных гражданских служащих и работников, замещающих должности, не являющиеся должностями федеральной государственной гражданской службы»[4], и Стратегическая карта развития ФНС России на 2020 2024 гг. 
В ходе исследования данной темы мы обратились к опыту Республики Хакасия, налоговые органы которой в ноябре 2020 года перешли на 2-х уровневую систему управления.

Так, например структура налоговых органов республики Хакассии выглядела до того как претерпела изменения.

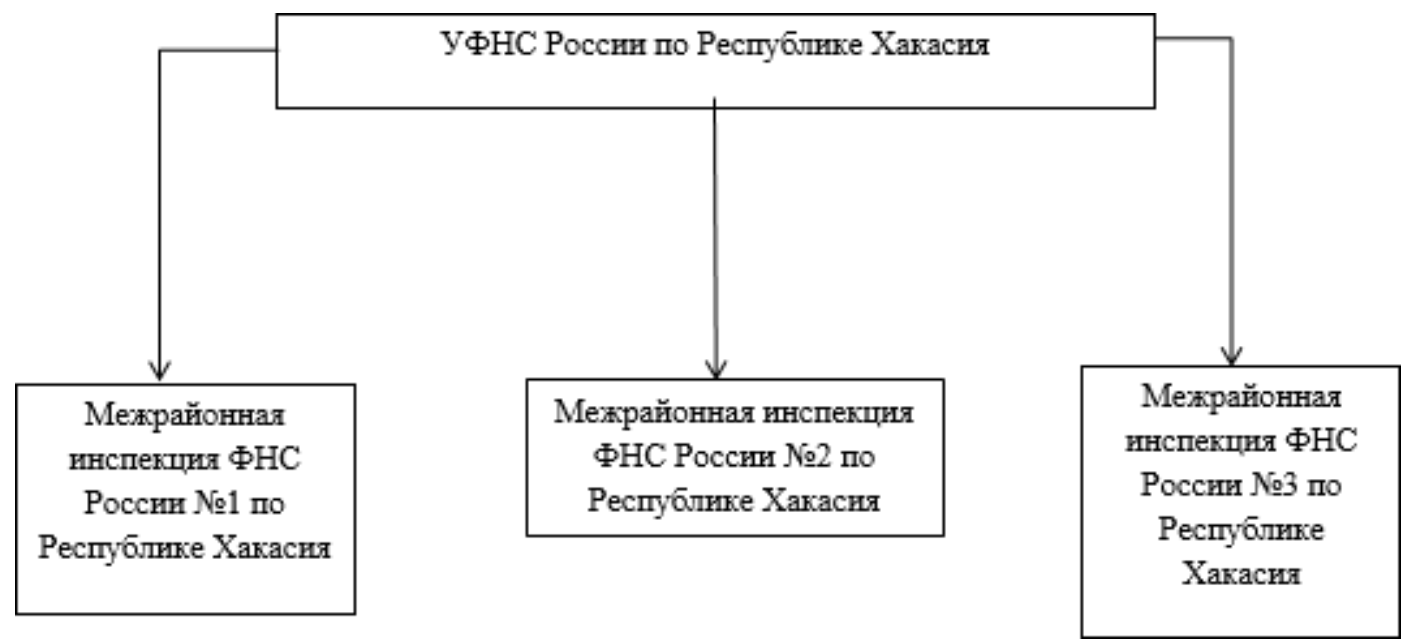

Рисунок 1. Организационная структура территориальных налоговых органов Республики Хакасия до модернизации

Так структура налоговых органов республики выглядит после реорганизации инспекций.

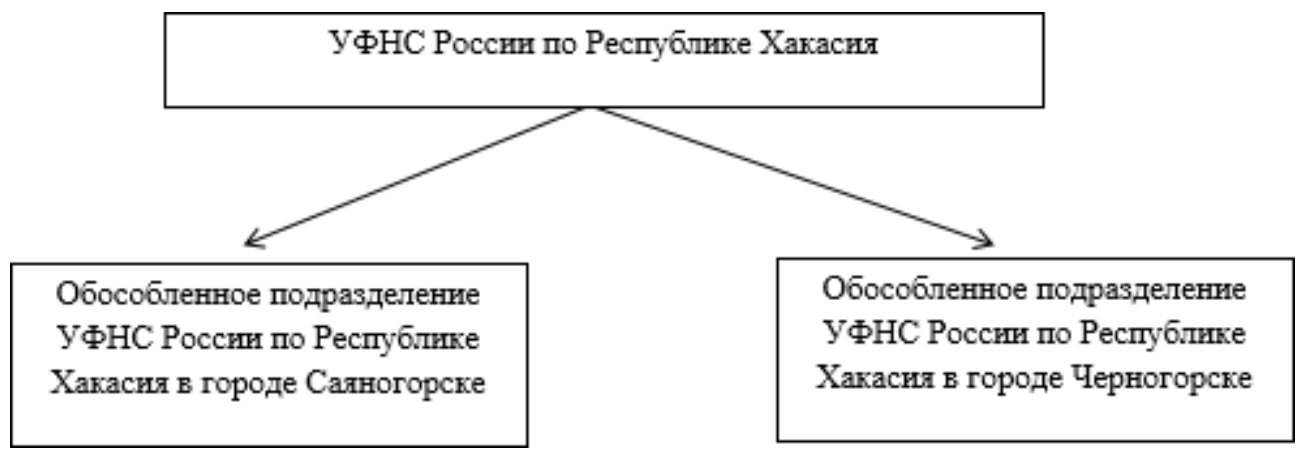

Рисунок 2. Организаџионная структура территориальных налоговых органов республики Хакасия после модернизации

Несмотря на все преобразования, граждане все же до конца не могут отказаться от личного посещения инспекции, так как не все категории граждан в настоящее время могут в полной мере использовать сервисы, которые нам предлагает фискальный орган, а некоторым категориям граждан, это даже иногда невозможно.

Поэтому в таких крупных городах республики Хакасия как город Саяногорск и Черногорск налоговой службой созданы обособленные подразделение УФНС России по Республике Хакасия.

В таких подразделениях налогоплательщик, являющийся юридическим или физическим лицом, может сдать налоговую и бухгалтерскую отчетность, получить информацию об уплате налогов, а также можно подать заявление на создание ИП, а именно получения свидетельства. 
Налоговым законодательством установлены сроки для предоставления отчетности, дачи объяснений по вопросам исчисления и уплаты налогов на которые необходимо оперативно реагировать, таким образом, актуальным элементом структуры налоговых органов на сегодняшний день остаются так называемые ТОРМы и обособленные подразделения при УФНС в субъектах.

ТОРМ - территориально-обособленное рабочее место территориального органа ФНС России[5].

Обособленное подразделение организации - любое территориально обособленное от нее подразделение, по месту нахождения которого оборудованы стационарные рабочие места[6].

На сегодняшний день налоговая служба является одной из стремительно развивающейся структурой в плане информационных технологий.

Создаются новые налоговые режимы, внедряются новые формы налогового контроля.

Конечно, данные изменения приводят к сокращению рабочих мест, к увеличению роли искусственного интеллекта, который пока не совсем совершенен и могут возникать сбои, неполадки, но в дальнейшем с развитие информационного общества, мы сможем увидеть совершенство информационных ресурсов без участия человека.

Подводя итог, можно сказать, что в настоящее время мероприятия, проводимые налоговой службой по модернизации организационной структуры, являются, в том числе следствием цифровизации налоговых органов начатой еще 2013 году.

Основной целью, которой является предоставление преимуществ для граждан и государства при обработке и использовании информации, а так же развитие экономики.

В настоящее время процессу информатизации в стране уделяется особое значение, это необходимо, прежде всего, для снижения бюджетных расходов, уменьшение уровня коррупции и социальной напряженности.

$$
* * *
$$

1. Налоговый кодекс Российской Федерации: федер. закон [от 31 июля 1998 года (с посл. изм. и доп.)] // Собр. законодательства Рос. Федерации. - 2019 г. -№ 50. - Ст.7244

2. Постановление Правительства РФ от 16 ноября 2020 г. № 1830 «Об оптимизации структуры и численности федеральных государственных гражданских служащих и работников, замещающих должности, не являющиеся должностями федеральной государственной гражданской службы, федеральных министерств, руководство деятельностью которых осуществляет Правительство Российской Федерации, федеральных служб и федеральных агентств, подведомственных этим федеральным министерствам, федеральных служб и федеральных агентств, руководство деятельностью которых осуществляет Правительство Российской Федерации» [Электронный pecypc] // - Режим доступа: https://www.garant.ru/products/ipo/prime/doc/74806326/

3. Приказ ФНС России от 25.02.2016 N MМВ-7-6/97@ (ред. от 26.12.2016) «Об утверждении Регламента взаимодействия территориальных органов ФНС России и ФКУ «Налог-Сервис» ФНС России при реализации функций по обработке налоговых документов, служащих основанием для исчисления и уплаты налогов, сборов и проведения мероприятий в отношении взаимозависимых лиц и контролируемых сделок, представляемых налогоплательщиками (их представителями) в территориальные органы ФНС России на бумажных носителях»[Электронный ресурс] // - Режим доступа: http://www.consultant.ru/document/cons_doc_LAW_194544/

4. Министерство цифрового развития, связи и массовых коммуникаций Российской Федерации [Электронный ресурс] // - Режим доступа: https://digital.gov.ru/ru/events/39738/

5. Миссия, основные направления деятельности и Стратегическая карта Федеральной налоговой $\begin{array}{llllll}\text { службы [Электронный } & \text { ресурс] }\end{array}$ https://www.nalog.gov.ru/rn77/about_fts/fts/ftsmission/

6. Статистика о представленных физическими лицами в налоговые органы уведомлениях об осуществлении деятельности по оказанию услуг физическим лицам для личных, домашних и (или) иных подобных нужд [Электронный ресурс] // - Режим доступа: https://www.nalog.gov.ru/rn77/related_activities/statistics_and_analytics/selfemployed/ 